Volume 6

\title{
The History of Nursing Education | L'histoire de la formation en sciences infirmières
}

Sioban Nelson

University of Toronto, sioban.nelson@utoronto.ca

Pauline Paul

University of Alberta, ppaul@ualberta.ca

Follow this and additional works at: https://qane-afi.casn.ca/journal

Part of the Higher Education Commons, and the Nursing Commons

\section{Recommended Citation}

Nelson, Sioban and Paul, Pauline (2020) "The History of Nursing Education I L'histoire de la formation en sciences infirmières," Quality Advancement in Nursing Education - Avancées en formation infirmière: Vol. 6: Iss. 2, Article 1. DOI: https://doi.org/10.17483/2368-6669.1267

This Editorial is brought to you for free and open access by Quality Advancement in Nursing Education - Avancées en formation infirmière. It has been accepted for inclusion in Quality Advancement in Nursing Education - Avancées en formation infirmière by an authorized editor of Quality Advancement in Nursing Education - Avancées en formation infirmière. 


\section{The History of Nursing Education}

The history of nursing education is a rich but sadly neglected topic for nursing historians and often overlooked by pedagogical researchers. As a result, we collectively know little of the critical choices, political successes, and extraordinary vision that led us to where we are today with Baccalaureate entry to practice for registered nurses almost everywhere in Canada, a wide range of advanced practice roles supported by master's programs throughout the country, and thriving $\mathrm{PhD}$ programs that produce highly successful researchers, innovative teachers, and visionary leaders in practice and in health care delivery.

The Call for Papers for this special issue was very broad and we were delighted with the response from across the country and abroad. The papers fall loosely into three categories: papers on pedagogy, the history of specialized areas of practice, and finally, the largest category, the history of the development of nursing education. Among the pedagogy papers Filice, Spadoni, Sevean and Dampier offer the reader creative perspectives and resources on ways to include Indigenous history as a pedagogical tool to work with students on questions of colonialism, racism and Indigenous knowledge. Lewenson and Bear-Lehman likewise provide an example of the utility of history is examining structural racism in the development of education in the health professions in the U.S. context. And in yet another example Landeen and colleagues highlight McMaster's iconic Problem Based Learning Curriculum (PBL) in their history of the McMaster School of Nursing. This paper also brings into focus the importance of strong clinical partnerships and collaborative research and clinical initiatives, as well as the challenges and opportunities that come from being a school in the shadow of a world-renowned medical school.

Specialized areas of nursing practice are the product of particular time-specific clinical or institutional needs. Both Boschma's and Lapeyre's submissions offer the reader a detailed understanding of these driving forces and the successes and failures of such initiatives. Geertje Boschma's paper on Mental Deficiency training and practice in Alberta in the post World War II period is a deeply contextual study of the widespread institutionalization of children and adults deemed 'subnormal' or deficient. Her sympathetic study highlights the limited opportunities for rural Albertans and the important role these institutions played in their local economies, as well as their muddled relationship with mainstream nursing. Jaime Lapeyre's piece on the American-led attempt to introduce public health nursing education and practice standards to post World War I Europe reveals the debates that ensued between American and British nurses concerning the ideal preparation for such nurses, and where they might sit within the health care and nursing structures of the day. It's the story of a nursing vision that failed to adapt to local contexts and thus failed to take root.

The development of nursing, its form and distinguishing features are highlighted in many of the papers, such as the failed attempt to introduce university education for nurses to Australia, as shown in Madonna Grehan's fascinating story of the abortive attempt to bring nursing education to the University of Melbourne in the 1930s. This paper contrasts markedly with the stalwart success of Ethel John's introduction of the baccalaureate program at the University of British Columbia in 1919, which set the stage for university education for nurses across the country, as described in Duncan, Scaia and Boschma's contribution. Evy Nazon's paper highlights the political nature of health care and the role it played in shaping nursing education in Canada. Nazon provides an overview of salient surveys of nursing education published in 1932 and 1961, and of their limited impact in driving change. Her paper makes the case that examining the evolution of nursing education in the context of the advent of the welfare state sheds light on how the needs of 
this state were a catalyst for change to nursing education. The role of missionaries in the white settlement of Canada and the colonization of Indigenous communities in BC is the focus of the Cook and Grypma paper on the Methodist Hospital in Bella Bella, BC. This paper brings to light the persistent whiteness of these initiatives and the difficulties in recovering Indigenous accounts and perspectives in the history of nursing and hospital foundation in Indigenous communities in Canada.

Finally, our interviews with two outstanding nurses, Professor Jacinthe Pepin and Dr. Marilynn (Marnie) Wood, bring to the fore the importance of vision and persistence in the advancement of nursing education in the country. Jacinthe Pepin, Professor at the Université de Montréal reminds us of the incredible importance of the Sisters of Charity of Montreal, known as the Grey Nuns, in the advancement of hospital care and nursing across the country. These highly networked nursing leaders with deep connections to colleagues in the US and across Canada included the country's first doctorally prepared Canadian nurse, Sister Denise Lefebvre. The Grey Nuns' careful stewardship of their school that would become la Faculté des sciences infirmières of the Université de Montréal was a landmark event, not simply for Canadian nursing, but for francophone nurses throughout the world.

Marilynn Wood, Professor Emerita and former Dean of the Faculty of Nursing, University of Alberta, gave us an exhilarating account of the patient and timely collaborative movement that brought in baccalaureate nursing as the entry-to-practice standard for registered nurses in that province. In a highly strategic consortium of all players: hospital schools of nursing, colleges and university, these Albertan nurse leaders took advantage of the policy window and moved as one. It was a model that worked because of relationships and trust and it became the model whereby the whole country shifted the needle towards a degree educated nursing workforce. She also shared the extraordinarily deft manoeuvre that brought the funding shift from the hospital programs to support the first funded $\mathrm{PhD}$ program in the country, established to support the education of faculty to produce a baccalaureate prepared workforce.

In closing, we would like to leave readers with suggestions about future historical research. There is a need for more comparative history of nursing education; for example, in a vast country like Canada it would be valuable to compare and contrast the history of nursing education in various provinces. It would also be revealing to explore in depth how nursing education leaders have influenced each other. Very few biographies of Canadian nursing education leaders have been written, and too often little about them is preserved in university archives. Collectively we must be vigilant and ensure that future historians will be able to write about nursing education in the 2020s. We must ensure that traces of our academic lives be preserved in University archives or other permanent archives. We all have a role to play in this. A dose of collective creativity could also be useful in making this happen. A simple way to get the ball rolling could be for example to design a course assignment where students interview faculty members, and where transcripts of these interviews are deposited at appropriate archives. It is up to us to make sure that our legacy will be visible.

Sioban Nelson, RN, PhD

Pauline Paul, PhD, RN 


\section{L'histoire de la formation en sciences infirmières}

L'histoire de la formation en sciences infirmières est un sujet riche, mais malheureusement oublié des historiens en sciences infirmières et souvent négligé par les chercheurs en pédagogie. Résultat : nous en savons peu collectivement sur les choix critiques, les succès politiques et la vision extraordinaire qui nous ont menés où nous en sommes aujourd'hui, avec le baccalauréat exigé pour/accéder à la pratique presque partout au Canada, avec un grand nombre de rôles de pratique infirmière avancée appuyés par des programmes de maîtrise à travers le pays, et avec des programmes de doctorat florissants qui produisent des chercheuses accomplies, des professeures innovatrices et des leaders visionnaires dans la pratique et la prestation des soins de santé.

L'appel à contributions pour cette édition spéciale était très large et nous sommes enchantées des réponses reçues du Canada et de l'étranger. Ces articles se classent dans trois catégories : les articles sur la pédagogie, sur l'histoire des domaines spécialisés de la pratique et finalement, représentant la catégorie la plus volumineuse, sur l'histoire du développement de la formation en sciences infirmières. Parmi les articles pédagogiques, les écrits de Filice, Spadoni, Sevean et Dampier offrent aux lectrices des points de vue créatifs et des ressources sur les façons d'intégrer l'histoire autochtone comme outil pédagogique pour aborder avec les étudiantes des sujets tels que le colonialisme, le racisme et les connaissances autochtones. Lewenson et Bear-Lehman offrent également un exemple de l'utilité de l'histoire pour étudier le racisme structurel dans le développement de la formation des professions en santé aux États-Unis. Un autre exemple, le travail de Landeen et collègues mettant en vedette le programme d'apprentissage iconique basé sur les problèmes de McMaster dans l'histoire de la McMaster School of Nursing. Cet article souligne également l'importance de partenariats cliniques, de recherches collaboratives solides et d'initiatives cliniques, ainsi que les défis et opportunités qui viennent avec le fait d'être une école dans l'ombre d'une école de médecine de renommée mondiale.

Les domaines spécialisés de la pratique infirmière sont le produit de besoins cliniques ou institutionnels spécifiques à une période. Les contributions de Boschma et Lapeyre offrent au lecteur une compréhension détaillée de ces forces motrices et des succès et échecs de ces initiatives. L'article de Geertje Boschma sur la formation et la pratique en déficience mentale en Alberta suivant la Deuxième Guerre mondiale est une étude contextuelle de l'institutionnalisation généralisée d'enfants et d'adultes considérés comme déficients ou «anormaux ». Son étude souligne les opportunités limitées des Albertains en milieu rural et le rôle important joué par ces institutions dans l'économie locale, ainsi que leur relation embrouillée avec les soins infirmiers traditionnels. L'article de Jaime Lapeyre sur la tentative américaine d'introduire des normes d'exercice et de formation en sciences infirmières en Europe après la Deuxième Guerre mondiale révèle les débats qui ont suivis entre les infirmières américaines et britanniques sur la préparation idéale de ces infirmières et leur place dans les structures de soins de santé et de soins infirmiers de l'époque. C'est l'histoire d'une vision des sciences infirmières qui n'a pas réussi à s'adapter aux contextes locaux, et qui n'a donc pas réussi à prendre racine.

Le développement des sciences infirmières, ainsi que de ses formes et de ses caractéristiques distinctives, sont abordés dans plusieurs articles, comme la tentative ratée d'instaurer une formation universitaire pour les infirmières en Australie, telle que décrite dans l'histoire fascinante de Madonna Grehan sur la tentative avortée d'introduire la formation en sciences infirmières à la University of Melbourne dans les années 30. Cet article offre un contraste flagrant avec le succès de l'introduction d'Ethel Johns du programme de baccalauréat en sciences infirmières à la University of British Columbia en 1919, initiative qui a mis la table pour la formation universitaire 
d'infirmières de partout au pays décrite par Duncan, Scaia et Boschma. L'article d'Evy Nazon parle de la nature politique des soins de santé et du rôle que ceux-ci ont joué dans l'élaboration de la formation en sciences infirmières au Canada. Nazon offre un aperçu des enquêtes marquantes sur la formation en sciences infirmières publiées en 1932 et en 1961 et de leur impact limité comme moteur de changements. Son article démontre que l'examen de l'évolution de la formation en sciences infirmières dans un contexte d'avènement de l'État providence fait la lumière sur la façon dont les besoins de cet état ont été un catalyseur pour les changements en formation en sciences infirmières. Le rôle des missionnaires dans les colonies blanches au Canada et la colonisation des communautés autochtones en Colombie-Britannique est le sujet de l'article de Cook et Grypma sur l'hôpital méthodiste à Bella Bella, dans cette même province. L'article met en lumière la blancheur persistante de ces initiatives et les difficultés à retrouver les points de vue autochtones dans l'histoire des sciences infirmières et la fondation des hôpitaux dans les communautés autochtones au Canada.

Et en dernier, nos entrevues avec deux infirmières extraordinaires, Professeure Jacinthe Pepin et la $\mathrm{D}^{\text {re }}$ Marilynn (Marnie) Wood, mettent de l'avant l'importance de la vision et la persistance dans l'avancement de la formation en sciences infirmières au pays. Jacinthe Pepin, professeure à l'Université de Montréal, nous rappelle l'importance incroyable des Sœurs de la Charité de Montréal, mieux connues comme les Sœurs Grises, dans l'avancement des soins hospitaliers et des soins infirmiers au pays. Ces chefs de file ayant un solide réseau en sciences infirmières, avec des connexions profondes avec des collègues aux États-Unis et au Canada, comptaient parmi elles la première infirmière au pays formée au doctorat, Sœur Denise Lefebvre. L'intendance prudente des Sœurs Grises de leur école, qui est devenue la faculté des sciences infirmières de l'Université de Montréal, a été un évènement marquant, non seulement pour les sciences infirmières au Canada, mais pour les infirmières francophones de partout dans le monde.

Marilynn Wood, professeure émérite et ancienne doyenne de la Faculty of Nursing de l' Université de l'Alberta, nous a offert un récit vivifiant du mouvement patient et collaboratif qui a fait du baccalauréat en sciences infirmières la norme d'entrée à la pratique des infirmières autorisées dans cette province. Dans un consortium stratégique regroupant tous les joueurs (écoles de sciences infirmières des hôpitaux, collèges et l'université), ces infirmières chefs de file albertaines ont tiré profit de l'ouverture politique et ont agi de concert. C'est un modèle qui a fonctionné grâce aux relations et à la confiance, et qui est devenu le modèle selon lequel le pays t a changé de cap vers une main-d'œuvre infirmière formée à l'université. Marilynn Wood a également partagé la manœuvre incroyablement habile qui a permis le changement un financement des programmes hospitaliers pour appuyer le premier programme de doctorat au pays, fondé pour soutenir l'éducation du corps professoral et ainsi produire une main-d'œuvre formée au baccalauréat.

Pour terminer, nous proposons aux lectrices des suggestions pour de futures recherches historiques. Il y a un besoin pour une histoire plus comparative de la formation en sciences infirmières; par exemple, dans un pays aussi vaste que le Canada, il serait utile de comparer et de faire le contraste entre l'histoire de la formation en sciences infirmières dans les différentes provinces. Il serait également révélateur d'explorer en profondeur l'influence qu'ont eue les chefs de file en formation en sciences infirmières les unes sur les autres. Peu de biographies ont été écrites sur les chefs de file en formation en sciences infirmières, et souvent, peu de renseignements à leur sujet sont conservés dans les archives des universités. Collectivement, nous devons rester vigilantes et nous assurer que les futurs historiens seront capables d'écrire sur la formation en sciences infirmières en 2020. Nous devons nous assurer que des traces de nos parcours 
académiques sont conservées dans les archives des universités ou d'autres archives permanentes. Nous avons un rôle à jouer, rôle qui pourrait être facilité par une dose de créativité collective. Une façon simple de lancer le mouvement pourrait être, par exemple, de concevoir un travail pour lequel les étudiantes doivent interroger les membres du corps professoral et de conserver la transcription de ces entrevues dans les archives appropriées. C'est à nous de nous assurer que notre héritage demeure visible.

Sioban Nelson, RN, PhD

Pauline Paul, PhD, RN 